\title{
Društveni aspekti matematičkog obrazovanja
}

\author{
Saša PUZIĆ, Branislava BARANOVIĆ \\ Institut za društvena istraživanja u Zagrebu, Hrvatska \\ puzic@idi.hr,baranov@idi.hr
}

\begin{abstract}
U radu se ispituje dvojna uloga matematičkog obrazovanja u društvu i to $\mathrm{s}$ jedne strane kao instrumenta tehnološkog i ekonomskog razvoja, a s druge kao mehanizma za postizanje društvenog statusa. U tu svrhu razmatra se uloga matematičkog obrazovanja u povećanju ekonomske produktivnosti i kompetitivnosti, u (re)produkciji društvenih nejednakosti, kao i njegova važnost za aktivno građanstvo. Polazeći od koncepata ljudskog kapitala i znanja visokog statusa, zastupa se teza da se ekonomski i statusni aspekt matematičkog obrazovanja ne mogu razmatrati odvojeno budući da aktualno (pre)naglašavanje ekonomskog aspekta pojačava tendenciju k obrazovnoj reprodukciji društvenih nejednakosti, što u konačnici može biti ekonomski disfunkcionalno. Autori naglašavaju potrebu za odmakom od obrazovnih politika usmjerenih primarno na ekonomsku učinkovitost pojedinca - shvaćenog kao apstraktnog nositelja ljudskog kapitala - prema politikama koje pitanje razvoja ljudskih resursa povezuju sa smanjenjem strukturnih nejednakosti u (matematičkom) obrazovanju i društvu općenito.
\end{abstract}

Ključne riječi: matematičko obrazovanje, ljudski kapital, znanje visokog statusa, aktivno građanstvo, postignuća iz matematike, obrazovna politika, postindustrijsko društvo

\section{Uvod}

Kad se govori o društvenoj relevantnosti matematike, nerijetko se ističe da matematika predstavlja »jezik znanosti« (Woodrow, 2003) i »jezik i metodologiju inženjera« te da se u tom smislu matematika može promatrati kao "preduvjet tehnologije ili tehnologija kao materijalizirana matematika« (Keitel, Kotzmann i Skovsmose, 1993: 245). Ovakva uloga matematike komplementarna je s tezom prema kojoj matematika predstavlja pokretačku snagu modernoga znanstvenog i tehnološkog razvoja čiji utjecaj na društvo 
do punog izražaja dolazi s razvojem suvremenih informacijskih i komunikacijskih tehnologija koje se konceptualno temelje na matematici (Keitel, 2006; usp. Mackay, 2007). Spomenuta se teza obrazlaže ubrzanim protokom sve većih količina informacija u različitim područjima društvenog života (Mackay, 2007) gdje proizvodnja, procesiranje i distribucija informacijskih dobara i usluga postaju osnovom novog načina proizvodnje utemeljenog na znanju (Bell, 1999; Castells, 2000). Izravna posljedica opisanih promjena jest primjena matematike u svim ključnim segmentima društva i sukladno tome njezina sve veća važnost za život pojedinca i društvo u cjelini. To znači i povećanje društvenih očekivanja i zahtjeva spram učinkovitosti matematičkog obrazovanja što se, sukladno opisanoj razvojno-tehnološkoj perspektivi, također argumentira utilitarno, tj. ulogom matematike i matematičkog obrazovanja u osiguravanju ljudskih resursa potrebnih za rješavanje egzistencijalnih i organizacijskih problema društva (Keitel, Kotzmann i Skovsmose, 1993).

S druge strane, i matematički i tehnološki razvoj odvijaju se uvijek u društvenom okruženju što ga određuju odnosi moći između pojedinaca i društvenih skupina (Weber, 1972; Bourdieu i Wacquant, 1992). Ovi odnosi moći utječu i na razvoj matematike i tehnologije budući da o njima ovisi kako društvena preferencija ciljeva matematičkih i tehnoloških istraživanja (Keitel, Kotzmann i Skovsmose, 1993) tako i obrasci društvenog isključivanja vezani uz ograničavanje dostupnosti matematičkog znanja za pojedine skupine u društvu (Popkewitz, 1988; Keitel, 2006). Dok spomenuta selektivnost u odabiru ciljeva matematičkih i tehnoloških istraživanja matematičkom znanju i tehnološkim strukturama daje legitimitet i praktično značenje, obrasci društvenog isključivanja slijede razlike u obrazovnom uspjehu prema socijalnom podrijetlu učenika. U slučaju matematičkog obrazovanja postojeća socijalna selektivnost obrazovnih sustava (Geißler, 2006) dobiva dodatno na težini budući da se obrazovna postignuća iz matematike s razmjerno visokom vjerojatnošću prevode u kasniju diferencijaciju na osnovi socioprofesionalnog statusa (Carnevale i Desrochers, 2003). S obzirom na rečeno u nastavku će se ispitati dvojna uloga matematičkog obrazovanja u društvu i to $s$ jedne strane kao instrumenta tehnološkog i ekonomskog razvoja, a s druge kao mehanizma statusne selekcije. U radu se zastupa teza da se ova dva aspekta matematičkog obrazovanja ne mogu promatrati odvojeno, odnosno da aktualno (pre)naglašavanje ekonomskog aspekta pojačava tendenciju $\mathrm{k}$ 
obrazovnoj reprodukciji društvenih nejednakosti, što u konačnici može biti ekonomski disfunkcionalno. U svrhu razmatranja ove teze najprije će se razmotriti uloga matematičkog obrazovanja u povećanju ekonomske produktivnosti i kompetitivnosti (I), zatim uloga matematičkog obrazovanja u (re)produkciji društvenih nejednakosti (II) i konačno njegova važnost za aktivno građanstvo (III). ${ }^{1}$ Kad govorimo o matematičkom obrazovanju, mislimo na matematičko obrazovanje u školskom sustavu.

\section{Tehnološki i ekonomski aspekti}

Iako javno obrazovanje postaje državnim interesom najkasnije u 19. st. (Hobsbawm, 1989), sveobuhvatna ekspanzija obrazovnih sustava u razvijenim industrijskim društvima nastupa u godinama nakon Drugoga svjetskog rata. Od pedesetih do sredine sedamdesetih godina 20. stoljeća, u razdoblju naglašenoga ekonomskog prosperiteta $\mathrm{i}$ društvenog razvoja, ${ }^{2} \mathrm{u}$ većini razvijenih zemalja dolazi do širokoga političkog konsenzusa prema kojemu obrazovanje predstavlja jednu od ključnih investicija u promicanju gospodarskog rasta i pravednijih društvenih odnosa (Brown i dr., 1997) ovdje ćemo, vezano ponajprije uz matematičko obrazovanje, reći nešto više o prvom aspektu (ekonomska učinkovitost), dok će se o drugom (pitanje jednakosti obrazovnih šansi i važnost matematičke pismenosti u ostvarivanju građanske uloge) raspravljati kasnije. Ekonomska uloga obrazovanja $\mathrm{u}$ razvijenim industrijskim društvima pritom se objašnjavala $u$ duhu sociološkog funkcionalizma, s dvjema međusobno povezanim pretpostavkama (Brown i dr., 1997): u razvijenim društvima ekonomska učinkovitost ovisi o obrazovnoj selekciji najsposobnijih pojedinaca za najvažnije i tehnološki najzahtjevnije poslove, ${ }^{3}$ dok istodobno, zbog usložnjavanja poslova u društvu, postoji potreba za proširenjem mogućnosti obrazovanja na svim obra-

\footnotetext{
${ }^{1} \mathrm{~S}$ obzirom na nerazvijenu istraživačku tradiciju u ovome području u Hrvatskoj u radu se najvećim dijelom referiramo na teorijske koncepte $\mathrm{i}$ istraživanja stranih autora.

${ }^{2}$ Brown i dr. (1997) poslijeratni društveni i ekonomski prosperitet u razvijenim industrijskim društvima objašnjavaju razvojem doktrine ekonomskog nacionalizma. Ova je doktrina kombinirala načela prosperiteta, sigurnosti i otvorenih mogućnosti kao temeljni okvir koji je povezivao politiku, poslovne organizacije, obitelj i obrazovanje u spomenutom razdoblju. Pritom je ključno bilo stajalište prema kojem nacionalna država ima moć, ali jednako tako i odgovornost da osigura prosperitet, sigurnost i otvorene mogućnosti za sve svoje građane.

${ }^{3}$ Pretpostavka je da u društvu postoji ograničen broj ljudi visoke inteligencije od kojih se zahtijeva da upravljaju društvenim razvojem te da ovaj ograničeni broj najsposobnijih treba biti selektiran i promoviran putem obrazovnog sustava.
} 
zovnim razinama. ${ }^{4}$ I u jednom i u drugom slučaju primarni je cilj ekspandirajućih obrazovnih sustava osiguravanje ekonomski učinkovitoga »ljudskog kapitala« pri čemu se misli na »znanja, vještine, kompetencije i sva druga svojstva osobe koja olakšavaju stvaranje osobnoga, društvenog i gospodarskog blagostanja« (za OECD Keeley, 2007: 29; usp. Woodhall, 1997; Pastuović, 2012). ${ }^{5}$ Drugim riječima, produženo se školovanje ne shvaća kao trošak za pojedinca i/ili društvo nego kao investicija koja će povećati individualnu produktivnost rada i tako pridonijeti ekonomskom rastu i društvenom razvoju na nacionalnoj razini (Chabbott i Ramirez, 2000).

Kad je riječ o ulaganju društva u »ljudski kapital« odnosno u znanja, vještine i kompetencije kojima pojedinci mogu pridonijeti »društvenom i gospodarskom blagostanju«, matematičkom se obrazovanju tradicionalno pridaje posebna važnost (Niss, 1981). Ovakvo se stajalište opravdava činjenicom da matematika razumljena kao »jezik znanosti« i matematičko obrazovanje stoje u osnovi tehnološkog i socioekonomskog razvoja društva. Važno je istaći da se opisana racionala u osnovi nije promijenila od sredine prošloga stoljeća, što ilustrira sljedeći programatski citat iz 1959.: »[Zalažemo se za matematičko obrazovanje] koje je jasno prepoznato kao istinski temelj tehnološkog društva [...] [P]rimorani smo reformirati naše poučavanje matematike kako bismo ga prilagodili i ojačali za utilitarnu ulogu nošenja sve težeg tereta znanstvene i tehnološke nadgradnje« (O.E.E.C., 1961, prema Skovsmose i Valero, 2001: 39). ${ }^{6}$ Drugim riječima, socioekonomski učinkovita primjena tehnologija u društvu zahtijeva matematički osposobljene pojedince.

Ovi se zahtjevi u javnom diskursu artikuliraju kao društvene potrebe za matematički i tehnološki stručnom radnom snagom, što prije ili kasnije utječe na oficijelni kurikulum i školski sustav u cjelini (Skovsmose, 1988).

\footnotetext{
${ }^{4}$ Većina poslova zahtijevat će višu razinu osposobljenosti, što će zahtijevati produljenje trajanja formalnog obrazovanja: »[P]olukvalificirani i nekvalificirani poslovi zamijenili bi se strojevima, dok bi radnici postali tehničari, menadžeri ili bi bili dodijeljeni rastućem sektoru usluga« (Brown i dr., 1997: 4).

${ }^{5}$ Kako upozoravaju Karabel i Halsey (1977) teorija ljudskog kapitala bila je u suglasju s teorijom funkcionalizma koja je privlačila mnoge sociologe pedesetih godina 20. stoljeća: »Obje teorije ističu tehničku funkciju obrazovanja i naglašavaju učinkovito korištenje ljudskih resursa《. Autori navode da su od kraja pedesetih »[v]ladine agencije [u SAD-u], privatne fondacije, i međunarodne organizacije poput Svjetske banke, MMF-a i OECD-a bile aktivno uključene u promoviranje teorije ljudskog kapitala« (Karabel i Halsey, 1977: 13).

${ }^{6}$ Citat je izvadak iz uvodnog predavanja što ga je 1959. održao matematičar M. H. Stone na seminaru Royaumont (Skovsmose i Valero, 2001).
} 
Od obrazovnog se sustava pritom očekuje da učenicima osigura potrebna znanja (matematike) za razumijevanje i rukovanje tehnologijom, da im na vrijednosnoj razini prenese »primjeren« stav prema tehnologiji, te da diferencira i selektira najsposobnije pojedince za socioekonomsku implementaciju različitih tehnologija (Keitel, Kotzmann i Skovsmose, 1993). Keitel, Kotzmann i Skovsmose ovu povezanost tehnoloških zahtjeva i matematičkog obrazovanja formuliraju ovako: »Dolazi do tehnološkog razvoja, prije ili kasnije formuliraju se implikacije za matematičko obrazovanje te se uvode promjene za koje se smatra da osiguravaju relevantne kvalifikacije - ne zbog epistemoloških ili obrazovnih razloga, nego uglavnom stoga što se matematika djelomično konvertira u tehnologiju « (Keitel, Kotzmann i Skovsmose, 1993: 247). Opisano razumijevanje matematičkog obrazovanja objašnjava njegovo tumačenje u kategorijama »ljudskog kapitala« i nacionalne ekonomske kompetitivnosti na globalnoj razini (Woodrow, 2003).

Premda tradicionalni ciljevi matematičkog obrazovanja nadilaze puku tehnološku i ekonomsku utilitarnost (Niss, 1981), razdoblje od osamdesetih do danas obilježava daljnji porast osnovne ekonomske orijentacije. Vrijeme je to rastuće globalizacije i kompeticije između nacionalnih ekonomija $\mathrm{u}$ kojemu ekonomski rast razvijenih zemalja ovisi sve više o investiranju u nove tehnologije i unapređivanju ljudskih resursa (Sahlberg, 2006). Pritom se osobito važnim pokazao razvoj novih informacijskih i komunikacijskih tehnologija temeljenih na matematici što objašnjava zašto se i u novome globalnom kontekstu matematičkom obrazovanju dodjeljuje središnja uloga. U okolnostima u kojima se obrazovanje, posebno matematičko obrazovanje shvaća kao jedan od ključnih elemenata ekonomskog prosperiteta i međunarodne ekonomske konkurentnosti (Haddad i dr., 1990; Woodrow, 2003; Keitel, 2006) rastu i društveni zahtjevi za unapređivanjem matematičkih vještina radne snage (Tate i Rousseau, 2002). Ti su zahtjevi vidljivi u stajalištima pojedinih vlada i stručnih tijela u kojima se zastupaju teze poput one da će »sve više radnika osposobljenih u matematici i prirodoslovnim disciplinama biti potrebno kako bi se održala međunarodna konkurentnost [SAD-a] « (U.S. Department of Education, 1997: 14), da »aktualne promjene u svjetskoj ekonomiji upućuju na to da će kvalitetna poduka u prirodoslovlju i matematici biti sve potrebnija za unapređenje produktivnosti i ekonomski razvoj« (za Svjetsku banku Haddad i dr., 1990) ili da je i unapređivanje matematičkog obrazovanja »apsolutna nužnost kako bi se zajamčila konkurentnost Europe na globalnom tržištu« (ERCIM News, 
2008). Ovi i slični primjeri ekonomskog razmišljanja dio su širega političkog ozračja u kojemu se ciljevi i predmetno područje (matematičkog) obrazovanja marginaliziraju ukoliko se u konačnici ne mogu opravdati ekonomskim interesom (Keitel, 2006).

Isticanje važnosti obrazovanja za ekonomski rast i razvoj argumentira se pritom rezultatima istraživanja o dugoročnoj isplativosti ulaganja $u$ obrazovanje odnosno ljudski kapital (Haddad i dr., 1990; Sahlberg, 2006; Hanushek i Wößmann, 2007). U zauzimanju ovakvog stajališta prednjače međunarodne financijske organizacije poput Svjetske banke i OECD-a (Karabel i Halsey, 1977; Chabbott i Ramirez, 2000) prema kojima investicije u ljudski kapital putem obrazovanja - pa tako i matematičkog obrazovanja - osiguravaju značajan porast produktivnosti te se općenito naglašava »visoka ekonomska isplativost ulaganja u obrazovanje [...] kako u apsolutnim iznosima, tako i u usporedbi s drugim investicijama« (za Svjetsku banku, Haddad i dr., 1990: 3). Ovakve su tvrdnje u skladu i s još razmjerno rijetkim analizama specifičnog doprinosa matematičkog obrazovanja prema kojima, među ostalim, postoji statistički značajan efekt obrazovnih postignuća iz matematike i prirodoslovlja (TIMSS, PISA i dr.) na dugoročni porast BDPa po glavi stanovnika na globalnoj razini (za Svjetsku banku, Hanushek i Wößmann, 2007). ${ }^{7}$ Navedena stajališta o isplativosti ulaganja u obrazovanje postaju dijelom novog »konsenzusa « prema kojem obrazovanje predstavlja ključ ekonomskog prosperiteta u razvijenim postindustrijskim društvima (Brown i dr., 1997; Llewellyn i Mendick, 2011). Za razliku od sličnih prijašnjih stajališta fokusiranih na nacionalni kontekst, novi se konsenzus pojavljuje sa spomenutim širenjem globalnog tržišta u kojem se ekonomska isplativost obrazovanja procjenjuje prema kriterijima globalne konkurentnosti. Potonja postaje lajtmotiv obrazovnih reformi usmjerenih prema podizanju standarda za znanja za koja se smatra da najviše utječu na kvalitetu ljudskog kapitala (matematičke, jezične i prirodoslovne kompetencije), dok se razmjerno manje pozornosti posvećuje pitanjima koja izlaze iz ovako zacrtanog okvira ekonomske isplativosti (npr. pitanja identiteta i jednakosti šansi različitih društvenih kategorija učenika) (usp. Brown i Lauder, 1997). U konačnici opisani je razvoj rezultirao »novim globalnim ortodoksijama« (Hargreaves i Goodson, 2006) u obrazovanju kojima je zajednički nazivnik

\footnotetext{
${ }^{7}$ Prema autorima, za razdoblje 1960-2000., rezultati testova iz matematike i prirodoslovlja koji su bolji za jednu standardnu devijaciju, povezani su s većom godišnjom stopom rasta BDP-a po glavi stanovnika za dva postotna poena (Hanushek i Wößmann, 2007: 32).
} 
restrukturiranje obrazovnih sustava prema ekonomističkim načelima tržišne kompetitivnosti, učinkovitosti i rezultatske odgovornosti (Apple, 2001; Sahlberg, 2006; Llewellyn i Mendick, 2011). ${ }^{8}$

Usprkos opisanom novom »konsenzusu« o važnosti obrazovanja u globalnoj postindustrijskoj ekonomiji (Brown i Lauder, 1997), kritičari upozoravaju da ne bi trebalo govoriti o izravnoj povezanosti obrazovanja i ekonomske produktivnosti bez da se uzmu u obzir posredujući faktori (Karabel i Halsey, 1977; Chabbott i Ramirez, 2000; Atweh, 2011). Takav posredujući faktor može npr. biti profesionalna struktura zaposlenih, pri čemu obrazovanje, uključujući i matematičko obrazovanje, može pridonijeti povećanju ekonomske produktivnosti pod pretpostavkom da pojedinci obavljaju ona zanimanja ili profesije za koje su obrazovani. Osim toga, viši se standardi obrazovanja pa tako i matematičkog obrazovanja mogu, s jedne strane tumačiti i kao rezultat ekonomskog razvoja (umjesto da mu prethode) ${ }^{9}$ (Woodrow, 2003), dok se s druge strane promjene u potražnji za radnom snagom ne mogu tretirati isključivo kao tehničko pitanje budući da uvijek odražavaju i prikrivene društvene interese i sukobe (Brown i dr., 1997; Chabbott i Ramirez, 2000). Potonje je pitanje vezano uz problematiku obrazovne socijalizacije i selekcije pa će se o njemu, kad je riječ ponajprije o matematičkom obrazovanju, više govoriti u nastavku.

\section{Matematičko obrazovanje i (re)produkcija društvenih nejedna- kosti}

Vidjeli smo da visoka tehnološka aplikabilnost matematičkog obrazovanja utječe na to da se matematičko obrazovanje općenito smatra ključnim za tehnološki i ekonomski razvoj društva. U tom smislu matematičko znanje Michael Apple naziva znanjem visokog statusa (engl. high status knowledge) čija akumulacija i kontrola postaje esencijalna u na znanosti utemeljenim ekonomijama (Apple, 1990, 1992). No za razliku od stajališta koja naglašavaju univerzalnu isplativost ulaganja u ljudski kapital, Apple ističe da je u razvijenim kapitalističkim ekonomijama bitno da je mate-

\footnotetext{
${ }^{8}$ Hargreaves i Goodson (2006) navode tri središnja elementa globalnih obrazovnih reformi od devedesetih do danas: središnji (od strane države propisani) kurikulumski i evaluacijski standardi, intenzivno evaluiranje i testiranje te poticanje kvazitržišne konkurencije i natjecateljstva među školama.

${ }^{9}$ Woodrow to ilustrira primjerom nekih ekonomski uspješnih azijskih zemalja kao što su Hong Kong ili Tajland čiji su uspjesi u međunarodnim testiranjima matematičkih kompetencija učenika slijedili ekonomski rast umjesto da su mu prethodili (Woodrow, 2003).
} 
matičko znanje kao oblik tehničkog/administrativnog znanja ${ }^{10}$ dostupno za primjenu, a ne nužno da ga posjeduje velik broj ljudi: »Iako je možda u interesu kapitala da ima prekomjernu ponudu osposobljenih radnika i općenito plaćenu radnu snagu koja je tehnički kompetentnija, moćne ekonomske skupine često tome daju samo retoričku podršku jer takav trošak ne smatraju opravdanim« (Apple, 1992: 421). Ako je Apple u pravu, posljedice takvoga stava za matematičko obrazovanje, za njegovu implementaciju i njegovu dostupnost za različite skupine u društvu, mogu biti dalekosežne. Ovo implicira premještanje fokusa od pitanja ekonomske učinkovitosti i apstraktnih nositelja ljudskog kapitala prema pitanjima vezanim uz društvene nejednakosti u obrazovanju.

U razdoblju suvremene obrazovne ekspanzije društvena se percepcija obrazovanja (kao mehanizma za povećanje ekonomske učinkovitosti i društvene pravde) u razvijenim industrijskim društvima temeljila na pretpostavci da objektivni i univerzalistički kriteriji vrednovanja i napredovanja na kojima počiva škola i koji vrijede jednako za sve učenike, pridonose ostvarivanju jednakosti u širem društvenom kontekstu (Flere, 1986). No unatoč politički i društveno utjecajnim stavovima o meritokratskom karakteru škole (Geißler, 2006), brojni istraživači osporavaju njezin neutralni karakter te upućuju na postojanost veze između obrazovnih i društvenih nejednakosti (Bourdieu, 1977; Lynch, 2000). U ovome ni matematičko obrazovanje nije iznimka. Štoviše, rašireno je mišljenje da upravo matematičko obrazovanje sa svojom »aureolom« znanstvene objektivnosti zauzima istaknutu poziciju u procesima obrazovne diferencijacije prema socijalnim kriterijima (Apple, 1992; Ladson-Billings, 1997; Skovsmose i Valero, 2001). ${ }^{11}$ Na ovome tragu Secada za SAD naglašava da različiti indikatori vezani uz matematičko obrazovanje (broj diploma u područjima bliskim matematici, postignuća iz matematike u školi, upis matematičkih smjerova ili karijere koje uključuju matematiku) ukazuju na sustavno zakidanje pojedinih skupina učenika. U tom smislu posebno se ističe »deprimirajuća povijest dokumentiranih dispariteta [...] između bijelaca i Amerikanaca azijskog podrijetla s jedne strane i Afroamerikanaca, Hispanoamerikanaca, američkih Indijanaca te

\footnotetext{
${ }^{10} \gg \mathrm{U}$ industrijskim društvima [matematičko znanje] stječe svoj visoki status zbog svoje socioekonomske korisnosti kao oblik nečega što sam zvao tehničko/administrativno znanje« (Apple, 1992: 420).

${ }^{11}$ Matematičko obrazovanje ima poziciju »čuvara« (engl. gatekeeper) koja mu omogućava kontrolu pristupa obrazovnim programima i institucijama.
} 
učenika nižega socioekonomskog statusa s druge« (Secada, 1989: 24). O ovim »deprimirajućim disparitetima« svjedoče podaci brojnih istraživanja koji pokazuju da se, primjerice »rasni« i etnički dispariteti u matematičkim postignućima učenika sustavno pojavljuju od devete godine nadalje, dok su razlike temeljene na socioekonomskom statusu prisutne od samoga početka školovanja (Matthews i dr., 1984, Kennedy, Jung i Orland, 1986, prema Secada, 1989). Kad je riječ o postojanosti nejednakih matematičkih postignuća, postojeće analize trendova pokazuju da se od početka osamdesetih razlike između »rasnih« i etničkih skupina u SAD-u lagano smanjuju, no da učenici afroameričkog i hispanskog podrijetla još uvijek postižu znatno lošije rezultate od bijelaca i učenika azijskog podrijetla na svim razinama obrazovnog sustava (Tate, 1997). Osim utjecaja »rasne« i etničke pripadnosti, spomenute analize trendova također dokumentiraju snažnu povezanost socioekonomskog statusa i matematičkih postignuća pri čemu učenici iz bolje stojećih obitelji, škola i lokalnih zajednica još uvijek postižu razmjerno bolje rezultate od drugih (Tate, 1997; usp. Lockheed i dr., 1985, prema Campbell, 1989). Kod interpretacije spomenutih nalaza različiti autori ukazuju na važnost moguće interakcije »rasne« i etničke pripadnosti i socioekonomskog statusa budući da je »siromaštvo u puno značajnijoj mjeri koncentrirano među afroameričkim i hispanskim učenicima nego među bijelcima« (Tate, 1997: 667; usp. Campbell, 1989).

Da se važnost spomenutih nalaza ne ograničava na SAD, svjedoče rezultati sličnih međunarodnih istraživanja (usp. Boaler, 2002; Woodrow, 2003) pa tako i rezultati međunarodnoga komparativnog istraživanja učeničkih postignuća iz matematike PISA (OECD, 2004; usp. Baumert i Schümer, 2001). ${ }^{12}$ Unatoč tome što škole trebaju osigurati primjerene i jednake mogućnosti za raznolike profile učenika rezultati ovoga istraživanja pokazuju da »socijalno podrijetlo učenika [home background] ostaje jedan od najvažnijih faktora koji utječe na postignuće« (OECD, 2004: 165). Pritom se naglašava da prosječna razlika u matematičkim postignućima između učenika čiji roditelji zauzimaju najprestižnija zanimanja (u područjima kao što su medicina ili pravo) i onih s najnižim statusom (primjerice rad

\footnotetext{
${ }^{12}$ Programme for International Student Assesment (PISA) je međunarodno komparativno istraživanje koje se u organizaciji OECD-a provodi od 2000. godine. Cilj istraživanja je ispitati u kojoj mjeri učenici pri završetku obveznog školovanja (u prosjeku 15. godina) raspolažu čitalačkom, matematičkom i prirodoslovnom kompetencijom. 2003. u istraživanju je sudjelovala 41 zemlja, a naglasak je bio na ispitivanju matematičkih kompetencija učenika (OECD, 2004).
} 
$\mathrm{u}$ poljoprivredi ili posluživanje $\mathrm{u}$ restoranu) iznosi u prosjeku jednu i pol kompetencijsku razinu. ${ }^{13}$ Ističe se također važnost i drugih indikatora socijalnog podrijetla, te se primjerice navodi da je odnos između obrazovanja majke i učeničkih postignuća iz matematike pozitivan i statistički značajan u svim sudjelujućim zemljama, odnosno da su posjedovanje i aktivnosti vezane uz »klasičnu« kulturu (npr. knjige klasične literature ili druga umjetnička djela) također povezane s uspjehom iz matematike. Osim spomenutih indikatora socijalnog podrijetla (zanimanje i obrazovanje roditelja, posjedovanje kulturnih dobara) koji se odnose na sve učenike, naglašava se i da učenici imigrantskog podrijetla, koji u većini pripadaju manjinskim etnojezičnim skupinama, u prosjeku postižu slabije rezultate od domaćih učenika. Ili preciznije, u zemljama u kojima učenici imigrantskoga podrijetla ${ }^{14}$ predstavljaju najmanje tri posto učenika ispitanih u PISA 2003, usporedba matematičkih postignuća učenika prve generacije, učenika rođenih u drugim zemljama i domicilnih učenika pokazuje velike i statistički značajne razlike u korist potonjih, a koje u pojedinim zemljama (Njemačka, Belgija) dosežu i više od dvije kompetencijske razine (OECD, 2004). ${ }^{15} \mathrm{Kad}$ je riječ o postignućima hrvatskih učenika, valja spomenuti da Hrvatska sudjeluje u PISA testiranju od 2006. godine. Kao i u većini zemalja, i u Hrvatskoj je ustanovljena povezanost socioekonomskog i sociokulturnog statusa učenika i postignutih rezultata na testiranju, pri čemu su učenici iz obitelji s višim socioekonomskim i sociokulturnim statusom postigli bolje rezultate (Braš Roth i dr., 2008; Braš Roth i dr., 2010; Gregurović i Kuti, 2010). Isti zaključak vrijedi i kad je riječ o učeničkim postignućima iz matematičke pismenosti. Dobiveni podaci pokazuju statistički značajnu povezanost indikatora socioekonomskog statusa s matematičkim postignućima učenika $\mathrm{s}$ tim da bolje rezultate postižu učenici čiji roditelji imaju više rangirano

${ }^{13}$ U Belgiji, Francuskoj, Njemačkoj, Mađarskoj, Luksemburgu, Slovačkoj i Lihtenštajnu ove su razlike posebno izražene. U tim zemljama učenici čiji roditelji zauzimaju najprestižnija zanimanja postižu u prosjeku rezultate na razini prosjeka postignuća iz matematike učenika u Finskoj, kao najbolje plasiranoj zemlji prema učeničkim postignućima iz matematike, čitanja i prirodoslovlja. Istodobno učenici čiji roditelji zauzimaju statusno najniža zanimanja postižu rezultate otprilike na razini najslabije plasiranih zemalja članica OECD-a (OECD, 2004: 165).

${ }^{14}$ Misli se na učenike koji su rođeni u zemljama u koje su njihovi roditelji doselili, tj. imigrirali.

${ }^{15}$ Ističe se da su dispariteti između učenika imigrantskoga podrijetla i domaćih učenika najveći u Njemačkoj, gdje su prosječne razlike u matematičkim postignućima između ovih dviju skupina učenika jednake dvjema kompetencijskim razinama. 
zaposlenje, koji su razmjerno bolje obrazovani, ${ }^{16}$ koji imaju bolje uvjete za učenje kod kuće i koji dolaze iz obitelji s više kulturnih dobara i većim brojem knjiga (Braš Roth i dr., 2008: 159). Jačina povezanosti izražena Pearsonovim r koeficijentom kreće se od 0,24 i 0,25 za uvjete za učenje kod kuće i za posjedovanje kulturnih dobara, do 0,32 za broj knjiga u obitelji, te 0,33 i 0,34 za indekse HISEI i ESCS.

Općenito uzevši, razmatrane razlike u matematičkim postignućima $u$ skladu su s osnovnim nalazom brojnih istraživanja školskog uspjeha različitih klasa i manjinskih etničkih skupina prema kojima se društvene nejednakosti putem obrazovanja prije održavaju nego što se smanjuju (Karabel i Halsey, 1977; Brown i dr. 1997; Lynch, 2000). ${ }^{17}$ Ovakvo se stanje može objasniti kako razlikama u socijalizacijskim iskustvima učenika iz socijalno privilegiranih i socijalno podređenih skupina (Bourdieu, 1977), tako i činjenicom da, i kod istih školskih postignuća, roditelji iz različitih društvenih skupina i slojeva za svoju djecu donose različite obrazovne odluke (Lareau i McNamara Horvat, 1999; Becker i Hecken, 2007). Pritom se pokazuje da u obitelji akumulirani kapital (raspolaganje simboličkim i materijalnim resursima, obrazovanje roditelja) utječe s jedne strane na »usklađenost« socijalizacijskih iskustava učenika s očekivanjima škole, a s druge na roditeljske aspiracije i stavove prema obrazovanju djece (Buchmann i Kriesi, 2010; usp. Bourdieu, 1982; Baumert i Schümer, 2001). Ili preciznije, institucionalizirana očekivanja nastavnika i drugih školskih djelatnika (koja oblikuju odnos prema učenicima i njihovim obrazovnim postignućima kao i obratno odnos učenika prema školi) bliža su navikama i dispozicija$\mathrm{ma}^{18}$ (domicilnih) učenika iz srednje ili više klase nego onima (manjinskih)

${ }^{16}$ To je iskazano kroz indekse HISEI i ESCS. »HISEI indeks generiran je na temelju određenih karakteristika zanimanja roditelja, pri čemu se novčani prihod pripisuje stupnju obrazovanja roditelja«, dok se »ESCS indeks bazira na HISEI indeksu, najvišem stupnju obrazovanja roditelja izraženom godinama obrazovanja te indeksima uvjeta za učenje kod kuće i kulturne imovine obitelji« (Braš Roth i dr., 2008: 159).

${ }^{17}$ Ovakva konstatacija nalazi svoju potvrdu i u sljedećem zaključku skupine autora: »Uloga obrazovanja u klasnoj reprodukciji i mobilnosti u industrijskim zemljama pokazuje dojmljivu uniformnost. [...] Nadnacionalna sličnost u ishodima, što će reći, obrazac socijalnog protoka, vjerojatno se postiže mehanizmom koji je isti u različitim zemljama, a odnosi se na razlike u učinkovitom korištenju obrazovnih resursa prema razlikama u klasnom podrijetlu« (Ishida, Müller i Ridge, 1995: 181).

${ }^{18}$ Spomenute razlike u kulturnim karakteristikama učenika Bourdieu objašnjava pojmom habitusa, pri čemu habitus definira kao sustav usvojenih dispozicija koje generiraju praksu sukladno postojećim strukturnim principima (Bourdieu, 1977). 
učenika nižega socioekonomskog statusa (Farkas i dr., 1990; Zevenbergen, 2001). S obzirom na to da i obrazovne aspiracije roditelja također rastu s obiteljskim statusom (Baumert i Schümer, 2001) ovakva konstelacija u konačnici učenicima višega socioekonomskog statusa daje veće obrazovne šanse u odnosu na učenike nižeg statusa (Bourdieu, 1977). U tom smislu Zevenbergen navodi da poučavanje matematike kod učenika prešutno pretpostavlja diskurzivno znanje i dispozicije srednje klase što »učenike radničkog podrijetla pozicionira kao marginalne« (Zevenbergen, 2001: 213). Ova se marginalizacija uobličuje kroz karakteristične interakcijske obrasce u razredu gdje primjerice »učenici višega socioekonomskog statusa pokazuju više povjerenja u svoje sposobnosti za sudjelovanje u raspravi i za rješavanje matematičkih problema, dok učenici nižega socioekonomskog statusa traže određenije upute od strane nastavnika i teksta« (Lubienski, 2001, prema Woodrow, 2003: 18). Opisane se razlike u postignućima u konačnici manifestiraju i kroz obrasce (ne)formalnog grupiranja prema socioekonomskom statusu učenika i njihovih roditelja (Lynch i Baker, 2005). Ovo uključuje sustavne nejednakosti u dostupnosti matematičkih sadržaja (ovisno o tipu škole i/ili razini programske diferencijacije u školi ili razredu), ${ }^{19}$ razlike u motivaciji i stručnoj osposobljenosti nastavnika matematike prema tipu škole i selektiranim skupinama kojima se predaje (razina kvalifikacije, nastavničko iskustvo i dr.), nejednakosti u financijskim resursima odnosno materijalnoj opremljenosti škola i dr. (Boaler, 2002; Tate i Rousseau, 2002).

No gore razmatrane razlike u matematičkim postignućima pojedinih skupina učenika još su značajnije ako se uzme u obzir važnost matematičkog obrazovanja za njihovo buduće pozicioniranje na tržištu rada. Na to upozoravaju Tate i Rousseau kad ističu da u SAD-u i brojnim drugim zemljama matematika predstavlja »akademsku putovnicu za ulaz u gotovo svako područje tržišta rada kao i za mogućnost studiranja « (Tate i Rousseau, 2002: 272; usp. Secada, 2011). Na istome tragu Carnevale i Desrochers (2003) ističu da je uspjeh u matematici nerijetko uvjet za pristup selektivnim fakultetima i za one studente koji upisuju programe izvan usko matematičkog područja. Autori ovaj visoki status matematičkog obrazovanja tumače sve većom važnošću kvantitativnih vještina (poznavanje i primjena

\footnotetext{
${ }^{19}$ Primjerice, za Veliku Britaniju se navodi da je $94 \%$ učenika u višem srednjem obrazovanju obuhvaćeno nekim oblikom unutarnje diferencijacije iz matematike. Pritom »se sastav različitih skupina oštro razdvaja prema klasnom podrijetlu, gdje su učenici iz srednje klase koncentrirani u višim skupinama, dok su učenici radničkog podrijetla u nižim « (Bartholomew, 2002, prema Bishop i Forgasz, 2007: 1158).
} 
računskih, statističkih i analitičkih postupaka) na tržištu rada u suvremenim postindustrijskim društvima, što potkrjepljuju projekcijom o gotovo dvije trećine očekivanih novih radnih mjesta u SAD-u koja će zahtijevati kvantitativne vještine na razini sadašnjih viših ili dodiplomskih studija (Carnevale i Desrochers, 2003).

Rastuća se potražnja za matematičkim obrazovanjem na tržištu rada razvijenih postindustrijskih društava odražava i u razlikama u materijalnom statusu. Primjer SAD-a s njegovom razmjerno liberalno reguliranom postindustrijskom ekonomijom (Brown i dr., 1997) u tom smislu može biti indikativan: »[I] ako su [od osamdesetih] razlike u primanjima između onih koji imaju i onih koji nemaju visokoškolsku naobrazbu rasle u svim disciplinama, najviše su rasle za one koji su sudjelovali u kurikulumima sa zastupljenijim matematičkim sadržajima, bez obzira na kasniju vrstu zanimanja« (Grogger i Eide, 1995, prema Carnevale i Desrochers, 2003: 22). Drugim riječima, u razvijenim postindustrijskim društvima, u kojima se od pojedinaca sve češće traži fleksibilnost i inventivnost u rješavanju problema (Mackay, 2007), oni s razvijenijim kvantitativnim vještinama zarađuju više od drugih. S obzirom na razmatrani utjecaj socijalnih faktora na uspjeh iz matematike, ovakav razvoj može, u određenoj mjeri, ${ }^{20}$ pojačati postojeću tendenciju k obrazovnoj reprodukciji različitih obrazaca (klasnih, etničkih i dr.) društvene nejednakosti.

Valja istaknuti da i u slučaju da je iznesena ekonomistička pretpostavka (o primarno tehnološki induciranoj potražnji za matematički osposobljenim ljudskim kapitalom) pretjerana (Brown i dr., 1997; Stehr, 2006), teza o središnjoj važnosti matematičkog obrazovanja za (re)produkciju društvenih nejednakosti zadržava sociološku relevantnost. O tome govori Apple (1992) kada naglašava da matematičko znanje zbog njegova tehnoutilitarnog karaktera predstavlja vrijedan te istodobno razmjerno rijedak društveni resurs (usp. Niss, 1994) čija se važnost proizvodnje, akumulacije i kontrole može sukobljavati sa zahtjevima za demokratskom društvenom distribucijom. U skladu s time zahtjevi za matematičkim obrazovanjem mogu predstavljati koliko tehničko pitanje za društvo u cjelini, toliko i pitanje vezano uz partikularne interese viših socioekonomskih skupina (Collins, 1971; Karabel i Halsey, 1977). U tom slučaju matematičko obrazovanje kao znanje viso-

\footnotetext{
${ }^{20}$ Potvrda ove pretpostavke ovisit će u konačnici o brojnim faktorima te će se razlikovati od zemlje do zemlje, odnosno od specifičnih socijalnih i obrazovnih politika (OECD, 2004).
} 
kog statusa (Apple, 1992) postaje pozicijsko dobro (u smislu zauzimanja određenoga društvenog položaja) potrebno za pristup elitnim zanimanjima i drugim privilegiranim položajima u društvu (Bourdieu, 1996; Skovsmose, 1998): »[M]atematika je koristan predmet za mnoge poslove i karijere. No često se koristi kao znak podobnosti za pristup takvim karijerama jednako koliko se koristi i u njima samima - dovodeći do isključivanja i zakidanja« (Atweh, 2011: 71). Elitistički karakter matematičkog obrazovanja povezan je pritom s činjenicom što formalni i neformalni zahtjevi vezani uz kvalifikacije ovoga tipa kontinuirano rastu (Collins, 1971), što u konačnici povlači za sobom potrebu za znatnim ulaganjima kulturnog i ekonomskog kapitala od strane uključenih pojedinaca (Bourdieu, 1996). ${ }^{21}$

Opisano se legitimiranje društvenih nejednakosti nanovo aktualizira u uvjetima recentnih obrazovnih reformi usredotočenih na zadovoljavanje potreba gospodarstva u globalnom kompetitivnom okruženju. Razlog tomu je što se u sklopu aktualnoga reformskog diskursa zahtjevi za višim obrazovnim standardima načelno predstavljaju kao pitanja meritokratske kompeticije, primjerice kao pitanja kvalitete poučavanja i učinkovitosti na razini pojedinih škola (usp. Fullan, 2000), dok se razmjerno manje pozornosti posvećuje pitanjima jednakosti i posebno strukturnim faktorima (poput socioekonomskog i/ili manjinskog statusa pojedinih skupina učenika) i njihovu utjecaju na postignuća u školi (Brown i dr, 1997). Na moguće negativne posljedice ovakvoga pristupa upozoravaju Bishop i Forgasz (2007) ističući da se »jednakost i kompeticija teško pomiruju«, odnosno da matematičko obrazovanje koncipirano na načelima natjecateljstva i nagrađivanja visokih no usko dostupnih postignuća, nužno zanemaruje argumente za promicanjem jednakosti obrazovnih šansi bez obzira na društvena obilježja učenika.

\section{Matematičko obrazovanje i aktivno građanstvo}

U prethodnom je dijelu ukazano na važnost socijalnog podrijetla učenika za uspjeh iz matematike kao i na činjenicu da se razlike u postignućima iz matematike s razmjerno visokom vjerojatnošću prevode u kasniju diferencijaciju na osnovi socioprofesionalnog statusa. No prethodno je također istaknuto da se obrazovni sustav kao i društvo u cjelini legitimiraju univer-

\footnotetext{
${ }^{21}$ Analizirajući socijalne i akademske karakteristike učenika nagrađenih na prestižnim (francuskim) nacionalnim ispitima Concours Général, Bourdieu ističe da »uspjeh iz matematike ili fizike [...] pretpostavlja posjedovanje veće količine kapitala nego uspjeh u humanističkim predmetima [...] [N]agrađeni iz matematike i fizike dolaze iz obitelji s društvenim i kulturnim prednostima« (Bourdieu, 1996: 59).
} 
zalistički ${ }^{22}$ te da se obrazovanje promatra i kao mehanizam za promicanje pravednijih društvenih odnosa (Flere, 1986). S obzirom na to da se pitanja društvene pravde $\mathrm{u}$ pravilu problematiziraju u kontekstu mogućih oblika političkog djelovanja (formalnog i neformalnog) i demokratske društvene participacije (Fraser, 1995) u nastavku će se promotriti mogući doprinos matematičkog obrazovanja osposobljavanju učenika za aktivno građanstvo, tj. konstruktivnu participaciju u promicanju demokratskih odnosa i procesa u društvu.

Od početka modernoga društvenog razvoja školi se dodjeljivala važna uloga u razvoju i održanju demokracije (Parsons, 1991). Sukus ovoga odnosa obrazlaže Dewey tvrdnjom da se demokracija ne može svesti na puki oblik vlasti, budući da demokracija predstavlja »ponajprije način zajedničkog života ljudi, iskustvo zajedničke komunikacije« (Dewey, 1916, prema Brown i dr., 1997). Shodno tomu uloga je obrazovanja da ljude pripremi za demokratski oblik »zajedničkog života i komunikacije«, odnosno da pojedincima omogući da postanu autonomni i za kritičko rasuđivanje osposobljeni odgovorni građani (McLaughlin, 1992; Skovsmose, 1998). U suvremenome obrazovnom kontekstu to znači da se aktivno građanstvo povezuje s obrazovanjem koje prenosi specifične socijalne i građanske kompetencije (European Communities, 2007), tj. znanja, vještine i stavove potrebne za sudjelovanje pojedinaca u društvenom i političkom životu i koje istodobno razvija kritičku svijest nužnu za propitivanje, raspravljanje i predlaganje alternativnih oblika demokratskog života (Arthur i Davison, 2000). Različiti autori ukazuju na specifičnu ulogu matematičkog obrazovanja u ovome (Niss, 1994; Skovsmose, 1998; Ball, Goffney i Bass, 2005).

U suvremenim razmatranjima uloge i svrhe matematičkog obrazovanja postoji stav da jedan od osnovnih ciljeva matematičkog obrazovanja treba biti osposobljavanje mladih za sudjelovanje u pluralističkom i demokratskom društvu (Niss, 2003; Ball, Goffney i Bass, 2005; Keitel, 2006; Atweh, 2011). Ovakvo naglašeno društveno tretiranje matematičkog obrazovanja umnogome duguje činjenici što se u suvremenom tehnološki strukturiranom kontekstu, društveni, politički i ekonomski interesi sve češće uobličavaju »matematičkim jezikom« (Skovsmose, 1998). Pritom rutinska primjena matematike $u$ društvu pretvara matematičke metode i matematičku argumentaciju u neupitna društvena pravila i ograničenja kojima se pojedinci

\footnotetext{
${ }^{22}$ Misli se na normativni zahtjev da se prema pojedincima postupa jednako sukladno općevrijedećim pravilima i kriterijima (usp. Parsons, 1991).
} 
i skupine moraju prilagoditi, dok istodobno učinkovitost matematiziranog društvenog poretka (u organizacijama i administraciji) ograničava praktični prostor za donošenje društvenih i političkih odluka (Keitel, 2006). Drugim riječima, demokratski se proces ograničava matematički i znanstveno legitimiranim činjenicama što pridonosi vladavini stručnjaka, dok oni koji nedovoljno vladaju matematičkim jezikom ostaju trajno isključeni iz procesa donošenja odluka u društvu. Nasuprot tomu, ako se pođe od normativnog zahtjeva za očuvanjem odnosno unapređenjem demokratske javne sfere $(u$ kojoj se ciljevi i sredstva javnih politika podvrgavaju kriteriju javne rasprave) (Habermas, 1996), otvoreno, kritičko i učinkovito matematičko obrazovanje za sve građane (u smislu matematičke pismenosti) postaje jedna od njegovih središnjih pretpostavki (Skovsmose, 1998).

U praktičnom smislu to znači da u suvremenom visoko tehnološkom društvu matematičko obrazovanje predstavlja nužan element građanske kompetencije koja po svojim karakteristikama (relevantnim znanjima i vještinama) nije fiksna nego se mijenja u skladu sa strukturnim promjenama u društvu (primjerice, u kontekstu osposobljavanja učenika i učenica za razumijevanje kvantitativnih prikaza ekonomskih kretanja, statističkih analiza procesa i pojava od općega društvenog interesa, vladinih odluka o sastavljanju ili promjenama budžeta, različitih metoda preračunavanja glasova u mandate na izborima i sl.) (Keitel, Kotzmann i Skovsmose, 1993). Pritom ovakvo osposobljavanje za aktivno građanstvo u pravilu podrazumijeva dva aspekta (Niss, 2003; usp. Ball, Goffney i Bass, 2005): razvoj matematičke pismenosti (mathematical literacy) koja uključuje praktična znanja i vještine potrebne u svakodnevnom društvenom, profesionalnom i privatnom $z_{\text {životu }}^{23}$ te širi emancipacijski aspekt (»liberating literacy« ili »popular enlightenment «) s istaknutom kritičkom odnosno normativnom perspektivom. Polazeći od normativnog određenja »zajednice slobodnih i jednakih« (građana) (Habermas, 1996), potonja se po pravilu veže uz asimetrije u odnosima moći između dominantnih segmenata društva i individualnog građanina (Niss, 1994) ili u radikalnijoj varijanti između privilegiranih i depriviranih skupina u društvu (Frankenstein, 1995). Oba spomenuta aspekta dotiču se u definiciji matematičke pismenosti prema PISA-i gdje je ona definirana kao »sposobnost pojedinca da prepozna i razumije ulogu koju matematika ima u svijetu, da donosi dobro utemeljene odluke i da primjenjuje ma-

\footnotetext{
${ }^{23}$ Rutinska primjena ovih znanja i vještina pojedincima omogućava kvalitetnije ostvarivanje njihovih obiteljskih, društvenih i profesionalnih uloga.
} 
tematiku na načine koji odgovaraju potrebama života tog pojedinca kao konstruktivnog, zainteresiranog i promišljajućeg građanina« (Braš Roth dr., 2010: 159). Matematička pismenost onda podrazumijeva i osposobljavanje građana za bavljenje temama i problemima od neposrednog društvenog značenja. Niss (2003) navodi važnost matematičkih vještina (npr. identificiranje, postavljanje i rješavanje problema uz pomoć kvantitativnih pokazatelja) za razumijevanje različitih društvenih tema, pri čemu ove teme mogu biti »političke, ekonomske, ili teme vezane za okoliš te se mogu odnositi na infrastrukturu, transport, na projekcije kretanja stanovništva, na izbor primjerenih lokacija za škole ili sportske objekte itd.« (Niss, 2003: 216). Prema tome autoru spomenute se teme mogu baviti i pitanjima bližim pojedincu »kao što su nadnice i plaće, rente i hipotekarni zajmovi, briga za djecu, osiguranja i mirovine, stambeni i građevinski propisi, kamatne stope i bankovne provizije itd.« (Niss, 2003: 216).

Teme koje navodi Niss ilustriraju univerzalnost primjene matematičkih vještina u različitim područjima društvenog života i samim time važnost matematičke pismenosti za sve uključene pojedince. No ranije je istaknuto kako matematičko osposobljavanje za aktivno građanstvo osim ovih praktičnih elemenata uključuje i kritičku perspektivu unutar koje matematika i matematičko obrazovanje predstavljaju »ključan resurs u izgradnji pravednog i raznolikoga demokratskog društva« (Ball, Goffney i Bass, 2005: 2; usp. Atweh, 2011). Ball, Goffney i Bass (2005) ističu da matematičko obrazovanje u tom smislu kod učenika može razvijati analitičke vještine potrebne za razmatranje društvenih nejednakosti, može predstavljati okvir za upoznavanje vlastitog i tuđega kulturnog naslijeđa, dok sama priroda matematičkog obrazovanja učenicima pomaže u prihvaćanju vrijednosti multiperspektivnosti i tolerancije i razvoju vještina racionalne argumentacije. Na povezanost matematičkog razumijevanja i razvoja kritičke perspektive učenika upozorava i Skovsmose. On naglašava da u suvremenim »matematički oblikovanim društvima« sposobnost zauzimanja kritičkog stava prema nekom problemu ovisi i o usvajanju kritičke distance prema matematičkom modelu kojim se taj problem često nastoji riješiti. Ili preciznije, osim što razvijaju pragmatično znanje, učenici trebaju razviti i sposobnost prepoznavanja ideja i interesa »koji se skrivaju iza zastora matematičkih formula« (Skovsmose, 1990: 112) kojima se legitimiraju ekonomske i političke odluke u društvu. Na istome tragu M. Frankenstein upozorava na moguće građansko pasiviziranje vezano uz matematičku neosposobljenost 
(engl. mathematical disempowerement) širokih slojeva stanovništva: »[M] atematički neosposobljena osoba nema adekvatan pristup podacima koji ruše mnoštvo raširenih mitova o klasnoj strukturi [...] Štoviše, čak i kad se pojave vijesti i priče s takvim podacima, matematički neosposobljeni pojedinci preskaču brojke ili ignoriraju cijelu priču« (Frankenstein, 1995: 169). Nasuprot ovome autorica naglašava da razvoj matematičkih vještina i matematičko opismenjavanje pridonose osvještavanju postojećih podjela $u$ društvu kao aktivirajućem elementu klasne svijesti i građanske participacije.

Spomenuti stav M. Frankenstein dobiva na važnosti s obzirom na prije razmatranu ulogu matematičkog obrazovanja kao znanja visokog statusa i kao svojevrsnoga kritičkog »čuvara« pristupa obrazovanju i tržištu rada. Štoviše, iz ove perspektive matematička neosposobljenost dijela građana i njihova time uvjetovana depolitizacija postaju konzervativan element društvenoga razvoja funkcionalan za održanje postojećih odnosa moći u društvu. S obzirom na to da obrazovna praksa reproducira ovaj konzervativni moment (Apple, 1990) pomaci prema egalitarnijim praksama ovisit će znatnim dijelom o osiguravanju materijalnih i simboličkih resursa za promicanje kritičke građanske perspektive u školi i širem društvu (Apple, 1992; Secada, 1995). Vidjeli smo da matematičkom osposobljavanju u ovome pripada istaknuta uloga.

U tom kontekstu treba spomenuti da ovaj stav dobiva i na političkoj važnosti. Potreba za kvalitetnim matematičkim obrazovanjem za sve građane i njegova važnost za ostvarivanje građanske uloge danas se politički promovira kroz ključne obrazovne dokumente OECD-a (PISA dokumenti) i Europske unije (Europski kompetencijski okvir). ${ }^{24}$ Ove su se ideje reflektirale i u obrazovnoj politici u Hrvatskoj pri čemu je u novom Nacionalnom okvirnom kurikulumu učinjen iskorak u definiranju matematičkog područja u smjeru naglašenijeg povezivanja matematičkog obrazovanja sa životom učenika i razumijevanjem važnosti i uloge matematike u društvu.

\section{Zaključna razmatranja}

Uvodno je istaknuto da se u suvremenim razvijenim društvima obrazovna ekspanzija u pravilu povezivala s dvama nadređenim ciljevima. S jedne

\footnotetext{
${ }^{24}$ Riječ je o dokumentu »Recommendation of the European Parliament and of the Council of 18 December for lifelong learning (2006/962/EC)« (European Commission, 2006) u kojem je definirano osam područja temeljnih kompetencija za cjeloživotno učenje, uključujući i matematičku kompetenciju.
} 
se strane smatralo da širenje obrazovanja doprinosi općem ekonomskom rastu i razvoju, a s druge da obuhvatnije obrazovanje promiče egalitarnije odnose u društvu. Naglašeno je također da u adresiranju ovih dvaju ciljeva matematičkom obrazovanju tradicionalno pripada istaknuta uloga te da se ono može promatrati kao faktor tehnološkog i ekonomskog razvoja društva i kao mehanizam za postizanje društvenog statusa. Naša je teza da se ova dva aspekta matematičkog obrazovanja ne mogu razmatrati odvojeno budući da aktualno (pre)naglašavanje ekonomskog aspekta pojačava tendenciju k obrazovnoj reprodukciji društvenih nejednakosti što u konačnici može biti ekonomski disfunkcionalno. U svrhu objašnjenja spomenute teze matematičko smo obrazovanje koncipirali kao oblik ulaganja u »ljudski kapital« (Woodhall, 1997) i kao »znanje visokog statusa« (Apple, 1990, 1992).

Srž teorije ljudskog kapitala sadržana je u pretpostavci prema kojoj "produljenje izloženosti školovanju povećava produktivnost « (Chabbott i Ramirez, 2000: 164) pri čemu veća produktivnost osigurava osnovu za ekonomski rast i razvoj na nacionalnoj razini. S obzirom na to da matematika kao jezik znanosti stoji u osnovi tehnološkog i ekonomskog razvoja društva, matematičkom se obrazovanju u tom smislu tradicionalno pridaje posebna važnost. No promatranje matematičkog obrazovanja isključivo iz ove perspektive prikriva činjenicu da se ne može govoriti o izravnoj povezanosti (matematičkog) obrazovanja i ekonomske produktivnosti, a da se ne uzmu u obzir posredujući faktori vezani uz odnose moći između pojedinaca i različitih skupina u društvu (Brown i dr. 1997). O tome govori Apple (1992) kad matematičko znanje naziva znanjem visokog statusa čija akumulacija i kontrola postaje esencijalnom u suvremenim visoko kompetitivnim ekonomskim sustavima. Za razliku od teorije ljudskog kapitala koja naglašava univerzalnu isplativost ulaganja u matematičko obrazovanje, Apple ističe da je u razvijenim kapitalističkim ekonomijama bitno da je matematičko znanje dostupno za primjenu, a ne nužno da ga posjeduje velik broj ljudi. U potonjem slučaju, iako se ne osporava da pridonosi ekonomskom razvoju društva, matematičko obrazovanje stječe značajke pozicijskog dobra, tj. dobra koje utječe na društvenu poziciju ili status pojedinca. U prilog tomu govore rezultati različitih istraživanja koja s jedne strane ukazuju na postojanost socioekonomskih i etničkih dispariteta u matematičkim postignućima učenika, a s druge na povećanje razlika u materijalnom statusu između onih koji imaju i onih koji nemaju formalnu matematičku naobrazbu (Carnevale i Desrochers, 2003). 
Iako neprihvatljivi s aspekta društvene pravednosti, opisani se dispariteti u suvremenom globalizacijskom kontekstu sve češće politički relativiziraju. Pritom ponajprije mislimo na tendenciju supsumiranja pitanja jednakosti šansi pod pitanja kvalitete i globalne konkurentnosti. Spomenuta tendencija proizlazi iz podređivanja obrazovanja ekonomskim ciljevima uz implicitnu poruku da domaće obrazovne nejednakosti postaju irelevantnima ako neka nacija uspije zadobiti kompetitivnu prednost u globalnoj utrci znanja i unapređivanja ljudskog kapitala (Brown i Lauder, 1997). Opisana racionala utječe na to da se zahtjevi za višim obrazovnim standardima načelno predstavljaju kao pitanja meritokratske učinkovitosti uz razmjerno zanemarivanje utjecaja društvenog okruženja na uspjeh u školi.

Umjesto toga smatramo da preokretanje spomenutih trendova vezanih uz društvene nejednakosti matematičkog obrazovanja zahtijeva odmak od obrazovnih politika usmjerenih primarno na ekonomsku učinkovitost pojedinaca - apstraktnih nositelja ljudskog kapitala, prema politikama koje pitanje razvoja ljudskih resursa povezuju sa smanjenjem strukturnih nejednakosti u obrazovanju i društvu općenito (usp. Fraser, 1995). Drugim riječima, adresiranje organizacijskih, sadržajnih i evaluacijskih karakteristika matematičkog obrazovanja i njemu pripadajućega obrazovnog sustava (struktura, kurikulum, sustav vrednovanja i dr.) trebalo bi biti popraćeno ponovnim priznavanjem jednakovrijednosti dvaju tradicionalnih ciljeva obrazovanja (ekonomska učinkovitost i društvena pravednost) i sukladno tomu refokusiranjem izvanjskih socioekonomskih karakteristika škola i njihovih učenika (Apple, 2001). U konačnici bi se pomaci prema pravednijem matematičkom obrazovanju procjenjivali ovisno o ravnomjernosti resursa kojima raspolažu škole, nastavnici i učenici, ravnomjernoj kvaliteti nastave (ovisno o znanjima, vještinama i stavovima nastavnika) i podjednakim ili sličnim obrazovnim karakteristikama (matematička postignuća, broj upisanih u školama i smjerovima s matematičkim kurikulumom, interes za matematiku) različitih skupina učenika (Allexsaht-Snider i Hart, 2001, prema Bishop i Forgasz, 2007). Ovakav bi razvoj, osim normativne (društvena pravednost), imao i ekonomsku opravdanost budući da se s jedne strane smanjuje tendencija prema monopoliziranju matematičkog znanja kao pozicijskog dobra, dok se istodobno povećava izvor ljudskih resursa u društvu: »Odnos između jednakosti i učinkovitosti na kraju 20. stoljeća [i u 21. st.] ne počiva samo na potvrđivanju meritokratskog načela u obrazovanju, nego i na shvaćanju da je bogatstvo ljudskih 
resursa neke nacije u obratnom odnosu spram društvenih nejednakosti« (Brown i Lauder, 1997: 188). Za samo matematičko obrazovanje to bi između ostalog značilo i da se pitanja kvalitete i podizanja standarda ne mogu promatrati odvojeno od pitanja jednakosti i osposobljavanja za aktivno i odgovorno građanstvo, tj. građanstvo koje podrazumijeva voljnost i sposobnost "za preuzimanje odgovornosti za prepoznavanje društvenih problema uz pomoć matematike kao i za predlaganje mogućih rješenja« (Llewellyn i Mendick, 2011; Atweh, 2011: 71).

Smatramo da potonja teza dobiva na važnosti i u hrvatskom kontekstu u kojem je uključivanje u PISA testiranje pridonijelo povećanom interesu javnosti za matematičko obrazovanje. Ove analize (Braš Roth i dr., 2008; Braš Roth i dr., 2010) indiciraju da jedan od značajnijih problema s kojim se suočava hrvatsko školstvo predstavljaju socioekonomski dispariteti u matematičkim postignućima učenika, što onda (sukladno tezi o štetnosti razdvajanja pitanja kvalitete i jednakosti) predstavlja zapreku postizanju bolje kvalitete matematičkog obrazovanja i, konzekventno tomu, izazov za obrazovnu politiku i škole u Hrvatskoj. U tom kontekstu također treba istaknuti i potrebu za intenzivnijim razvojem znanstvenih istraživanja društvenih aspekata i društvene uloge matematičkog obrazovanja koja su u Hrvatskoj zanemarena, a bez kojih nije moguće sagledati važnost matematičkog obrazovanja za društveni, ekonomski i politički razvoj.

\section{LITERATURA}

Apple, Michael W. (1990). Ideology and Curriculum. New York: Routledge.

Apple, Michael W. (1992). »Do the Standards Go Far Enough? Power, Policy, and Practice in Mathematics Education«, Journal for Research in Mathematics Education, 23 (5): 412-431. doi:10.2307/749562

Apple, Michael W. (2001). »Comparing Neo-liberal Projects and Inequality in Education«, Comparative Education, 37 (4): 409-423. doi:10.1080/03050060120091229

Arthur, James i Davison, Jon (2000). »Social literacy and citizenship education in the school curriculum«, The Curriculum Journal, 11 (1): 9-23. doi:10.1080/095851700361366

Atweh, Bill (2011). »Quality and Equity in Mathematics Education as Ethical Issues«, u: Bill Atweh, Mellony Graven, Walter Secada i Paola Valero (ur.). Mapping Equity and Quality in Mathematics Education. New York: Springer, str. 63-75.

Ball, Deborah Loewenberg, Goffney, Imani Masters i Bass, Hyman (2005). »The Role of Mathematics Instruction in Building a Socially Just and Diverse Democracy«, The Mathematics Educator, 15 (1): 2-6. 
Baumert, Jürgen i Schümer, Gundel (2001). »Familiäre Lebensverhältnisse, Bildungsbeteiligung und Kompetenzerwerb«, u: Deutsches PISA-Konsortium (ur.). PISA 2000: Basiskompetenzen von Schülerinnen und Schülern im internationalen Vergleich. Opladen: Leske und Budrich, str. 323-407.

Becker, Rolf i Hecken, Anna Etta (2007). »Studium oder Berufsausbildung? Eine empirische Überprüfung der Modelle zur Erklärung von Bildungsentscheidungen von Esser sowie von Breen und Goldthorpe«, Zeitschrift für Soziologie, 36 (2): 100-117.

Bell, Daniel (1999 [1973]). The Coming of Post-Industrial Society. New York: Basic Books.

Bishop, Alan J. i Forgasz, Helen J. (2007). »Issues in Access and Equity in Mathematics Education«, u: Frank K. Lester, Jr. (ur.). Second Handbook of Research on Mathematics Teaching and Learning. Charlotte: Information Age Publishing, str. 1145-1167.

Boaler, Jo (2002). Experiencing School Mathematics. New Jersey: Lawrence Erlbaum.

Bourdieu, Pierre (1977). »Cultural Reproduction and Social Reproduction«, u: Jerome Karabel i A. H. Halsey (ur.). Power and Ideology in Education. New York: Oxford University Press, str. 487-511.

Bourdieu, Pierre (1982 [1979]). Die feinen Unterschiede. Kritik der gesellschaftlichen Urteilskraft. Frankfurt am Main: Suhrkamp.

Bourdieu, Pierre (1996 [1989]). The State Nobility. Cambridge: Polity Press.

Bourdieu, Pierre i Wacquant, Loïc J. D. (1992). An Invitation to Reflexive Sociology. Cambridge: Polity Press.

Braš Roth, Michelle, Gregurović, Margareta, Markočić Dekanić, Ana i Markuš, Marina (2008). PISA 2006 - Prirodoslovne kompetencije za život. Zagreb: Nacionalni Centar za vanjsko vrednovanje obrazovanja - PISA centar.

Braš Roth, Michelle, Markočić Dekanić, Ana, Markuš, Marina i Gregurović, Margareta (2010). PISA 2009 - Čitalačke kompetencije za život. Zagreb: Nacionalni Centar za vanjsko vrednovanje obrazovanja - Centar PISA.

Brown, Philip, Halsey, A. H., Lauder, Hugh i Wells, Amy Stuart (1997). »The Transformation of Education and Society: An Introduction«, u: A. H. Halsey, Hugh Lauder, Philip Brown i Amy Stuart Wells (ur.). Education: Culture, Economy, and Society. Oxford: Oxford University Press, str. 1-44.

Brown, Philip i Lauder, Hugh (1997). »Education, Globalization, and Economic Development«, u: A. H. Halsey, Hugh Lauder, Philip Brown i Amy Stuart Wells (ur.). Education: Culture, Economy, and Society. Oxford: Oxford University Press, str. 172-192.

Buchmann, Marlis i Kriesi, Irene (2010). »Schuleintritt und Schulleistungen im mittleren Primarschulalter«, Schweizerische Zeitschrift für Soziologie, 36 (2): 325-344.

Campbell, Patricia B. (1989). »So What Do We Do with the Poor, Non-White Female? Issues of Gender, Race, and Social Class in Mathematics and Equity«, Peabody Journal of Education, 66 (2): 95-112. doi:10.2307/1492540

Carnevale, Anthony P. i Desrochers, Donna M. (2003). »The Democratization of Mathematics«, u: Bernard L. Madison i Lynn Arthur Steen (ur.). Quantitative 
Literacy: Why Numeracy Matters for Schools and Colleges. Princeton: The National Council on Education and the Disciplines, str. 21-31.

Castells, Manuel (2000 [1996]). Uspon umreženog društva. Zagreb: Golden marketing.

Chabbott, Colette i Ramirez, Francisco O. (2000). »Development and Education«, $\mathrm{u}$ : Maureen T. Hallinan (ur.). Handbook of the Sociology of Education. New York: Springer, str. 163-187.

Collins, Randall (1971). »Functional and Conflict Theories of Educational Stratification«, American Sociological Review, 36 (6): 1002-1019. doi:10.2307/2093761

ERCIM News (2008). The Future of Mathematics Education in Europe. ERCIM News, April, 2008, http://ercim-news.ercim.eu/the-future-of-mathematics-education-in-europe.

European Commission (2006). Recommendation of the European Parliament and of the Council of 18 December for lifelong learning (2006/962/EC). Brussels.

European Communities (2007). European Reference Framework: Key Competences for Lifelong Learning. Luxembourg: Office for Official Publications of the European Communities.

Farkas, George, Grobe, Robert P., Sheehan, Daniel i Shuan, Yuan (1990). »Cultural Resources and School Success: Gender, Ethnicity, and Poverty Groups within an Urban School District«, American Sociological Review, 55 (1): 127142. doi:10.2307/2095708

Flere, Sergej (ur.) (1986). Proturječja suvremenog obrazovanja: ogledi iz sociologije obrazovanja. Zagreb: RZ RKSSO.

Frankenstein, Marilyn (1995). »Equity in mathematics education: Class in the world outside the class«, u: Walter G. Secada, Elizabeth Fennema i Lisa Byrd Adajian (ur.). New Directions for Equity in Mathematics Education. New York: Cambridge University Press, str. 165-190.

Fraser, Nancy (1995). »From Redistribution to Recognition? Dilemmas of Justice in a 'Post-Socijalist Age'«, New Left Review, 212: 68-93.

Fullan, Michael (2000). The Three Stories of Education Reform, http://pil.numplus. com/SchoolLeadership/04-fullan/Resources/The_Three_Stories_of_Education Reform.pdf.

Geißler, Rainer (2006). »Bildungschancen und soziale Herkunft«, Archiv für Wissenschaft und Praxis der sozialen Arbeit, (4): 34-49.

Gregurović, Margareta i Kuti, Simona (2010). »Učinak socioekonomskog statusa na obrazovno postignuće učenika: Primjer PISA istraživanja, Hrvatska 2006.«, Revija za socijalnu politiku, 17 (2): 179-196. doi:10.3935/rsp.v17i2.918

Habermas, Jürgen (1996). Die Einbeziehung des Anderen. Frankfurt am Main: Suhrkamp.

Haddad, Wadi D., Carnoy, Martin, Rinaldi, Rosemary i Regel, Omporn (1990). Education and Development: Evidence for New Priorities. Washington: The World Bank.

Hanushek, Eric A. i Wößmann, Ludger (2007). The Role of Education Quality in Economic Growth. Washington: The World Bank.

Hargreaves, Andy i Goodson, Ivor (2006). »Educational Change Over Time? The Sustainability and Nonsustainability of Three Decades of Secondary School 
Change and Continuity«, Educational Administration Quarterly, 42 (1): 3-41. doi:10.1177/0013161X05277975

Hobsbawm, Eric (1989 [1975]). Doba kapitala: 1848-1875. Zagreb: Školska knjiga i Stvarnost.

Ishida, Hiroshi, Müller, Walter i Ridge, John M. (1995). »Class Origin, Class Destination, and Education: A Cross-National Study of Ten Industrial Nations«, American Journal of Sociology, 101 (1): 145-193. doi:10.2307/2782508

Karabel, Jerome i Halsey, A. H. (1977). »Educational Research: A Review and an Interpretation«, u: Jerome Karabel i A. H. Halsey (ur.). Power and Ideology in Education. New York: Oxford University Press, str. 1-85.

Keeley, Brian (2007). Human capital: How what you know shapes your life. Paris: OECD. http://www.oecd.org/insights/humancapitalhowwhatyouknowshapesyourlife.htm.

Keitel, Christine (2006). »Mathematics, Knowledge and Political Power«, u: Jürgen Maasz i Wolfgang Schloeglmann (ur.). New Mathematics Education Research and Practice. Rotterdam: Sense Publishers, str. 11-22.

Keitel, Christine, Kotzmann, Ernst i Skovsmose, Ole (1993). »Beyond the Tunnel Vision: Analysing the Relationship between Mathematics, Society and Technology«, u: Christine Keitel i Kennet Ruthven (ur.). Learning from Computers: Mathematics Education and Technology. Berlin: Springer, str. 242-279.

Ladson-Billings, Gloria (1997). »It Doesn't Add up: African American Students' Mathematics Achievement«, Journal for Research in Mathematics Education, 28 (6): 697-708. doi:10.2307/749638

Lareau, Annette i McNamara Horvat, Erin (1999). »Moments of Social Inclusion and Exclusion: Race, Class, and Cultural Capital in Family-School Relationships«, Sociology of Education, 72 (1): 37-53. doi:10.2307/2673185

Llewellyn, Anna i Mendick, Heather (2011). »Does Every Child Count? Quality, Equity and Mathematics with/in Neoliberalism«, u: Bill Atweh, Mellony Graven, Walter Secada i Paola Valero (ur.). Mapping Equity and Quality in Mathematics Education. New York: Springer, str. 49-62.

Lynch, Kathleen (2000). »Research and Theory on Equality and Education«, u: Maureen T. Hallinan (ur.). Handbook of the Sociology of Education. New York: Springer, str. 85-105.

Lynch, Kathleen i Baker, John (2005). »Equality in education: An equality of condition perspective«, Theory and Research in Education, 3 (2): 131-164. doi: $10.1177 / 1477878505053298$

Mackay, Hugh (2007). »Information society«, u: George Ritzer (ur.). The Blackwell Encyclopedia of Sociology. Malden, USA: Blackwell, str. 2326-2331.

McLaughlin, T. H. (1992). »Citizenship, Diversity and Education: A Philosophical Perspective«, Journal of Moral Education, 21 (3): 235-250. doi:10.1080/ 0305724920210307

Niss, Mogens (1981). »Goals as a Reflection of the Needs of Society«, u: R. Morris (ur.). Studies in mathematics education. Paris: UNESCO, str. 1-21.

Niss, Mogens (1994). »Mathematics in Society«, u: Rolf Biehler, Roland W. Scholz, Rudolf Straesser i Bernard Winkelmann (ur.). Didactics of Mathematics as a Scientific Discipline. Dordrecht: Kluwer Academic Publishers, str. 367-378. 
Niss, Mogens (2003). »Quantitative Literacy and Mathematical Competencies«, u: B. L. Madison i L. A. Steen (ur.). Quantitative Literacy: Why Numeracy Matters for Schools and Colleges. Princeton: The National Council on Education and the Disciplines, str. 215-220.

OECD (2004). Learning for Tommorow's World: First Results from PISA 2003. Paris: OECD.

Parsons, Talcott (1991). Društva. Zagreb: August Cesarec.

Pastuović, Nikola (2012). Obrazovanje i razvoj. Zagreb: Institut za društvena istraživanja u Zagrebu i Učiteljski fakultet Sveučilišta u Zagrebu.

Popkewitz, Thomas S. (1988). »Institutional Issues in the Study of School Mathematics: Curriculum Research«, Educational Studies in Mathematics, 19 (2): 221-249. doi:10.2307/3482576

Sahlberg, P. (2006). »Education Reform for Raising Economic Competitiveness«, Journal of Educational Change, 7 (4): 259-287. doi:10.1007/s10833-005-4884-6

Secada, Walter G. (1989). »Agenda Setting, Enlightened Self-Interest, and Equity in Mathematics Education«, Peabody Journal of Education, 66 (2): 22-56. doi: $10.2307 / 1492537$

Secada, Walter G. (1995). »Social and critical dimensions for equity in mathematics education«, u: Walter G. Secada, Elizabeth Fennema i Lisa Byrd Adajian (ur.). New Directions for Equity in Mathematics Education. New York: Cambridge University Press, str. 146-164.

Secada, Walter G. (2011). »The Theoretical Landscape«, u: Bill Atweh, Mellony Graven, Walter Secada i Paola Valero (ur.). Mapping Equity and Quality in Mathematics Education. New York: Springer, str. 123-127.

Skovsmose, Ole (1988). »Mathematics as Part of Technology«, Educational Studies in Mathematics, 19 (1): 23-41. doi:10.1007/BF00428383

Skovsmose, Ole (1990). »Mathematical Education and Democracy«, Educational Studies in Mathematics, 21 (2): 109-128. doi:10.1007/BF00304897

Skovsmose, Ole (1998). »Linking Mathematics Education and Democracy: Citizenship, Mathematical Archaeology, Mathemacy and Deliberative Interaction«, ZDM, 30 (6): 195-203. doi:10.1007/s11858-998-0010-6

Skovsmose, Ole i Valero, Paola (2001). »Breaking Political Neutrality: The Critical Engagement of Mathematics Education with Democracy«, u: Bill Atweh, Helen Forgasz i Ben Nebres (ur.). Sociocultural Research on Mathematics Education: An International Perspective. New Jersey: Lawrence Erlbaum, str. 37-55.

Stehr, Nico (2006). »Aktuelle Probleme der Wissensgesellschaft: Bildung, Arbeit und Wirtschaft«, u: Klaus Kempter i Peter Meusburger (ur.). Bildung und Wissensgesellschaft. Heidelberg: Springer, str. 363-377.

Tate, William F. (1997). »Race-Ethnicity, SES, Gender, and Language Proficiency Trends in Mathematics Achievement: An Update«, Journal for Research in Mathematics Education, 28 (6): 652-679. doi:10.2307/749636

Tate, William i Rousseau, Celia (2002). »Access and Opportunity: The Political and Social Context of Mathematics Education«, u Lyn D. English (ur.). Handbook of International Research in Mathematics Education. New Jersey: Lawrence Erlbaum, str. 271-299. 
U.S. Department of Education (1997). White Paper: Mathematics Equals Opportunity. Washington: U.S. Department of Education.

Weber, Max (1972 [1922]). Wirtschaft und Gesellschaft: Grundriß der verstehenden Soziologie. Tübingen: Mohr.

Woodhall, Maureen (1997). »Human Capital Concepts«, u: A. H. Halsey, Hugh Lauder, Philip Brown i Amy Stuart Wells (ur.). Education: Culture, Economy, and Society. Oxford: Oxford University Press, str. 219-223.

Woodrow, Derek (2003). Mathematics, Mathematics Education and Economic Conditions. http://www.esri.mmu.ac.uk/respapers/papers-pdf/Paper\%20-\%20maths, $\%$ 20maths $\% 20$ ed $\% 20 \% 26 \% 20$ economics.pdf.

Zevenbergen, Robyn (2001). »Mathematics, Social Class, and Linguistic Capital: An Analysis of Mathematics Classroom Interactions«, u: Bill Atweh, Helen Forgasz i Ben Nebres (ur.). Sociocultural Research on Mathematics Education: An International Perspective. New Jersey: Lawrence Erlbaum, str. 201-215.

\title{
Social Aspects of Mathematics Education
}

\author{
Saša PUZIĆ, Branislava BARANOVIĆ \\ Institute for Social Research, Zagreb, Croatia \\ puzic@idi.hr,baranov@idi.hr
}

The paper examines the dual role of mathematics education in society, on the one hand as an instrument of technological and economic development, and on the other as a mechanism for status attainment. Therefore, the authors discuss the role of mathematics education in raising economic competitiveness and productivity, in the (re)production of social inequalities, and its relevance for active citizenship. Drawing on the concepts of human capital and high status knowledge, it is asserted that the economic and status attainment aspects of mathematics education cannot be separated, since the actual (over)accentuation of the economic aspect strengthens the tendency for educational reproduction of social inequalities, which in the end can be economically dysfunctional. The authors emphasise the need for retreat from educational policies focused primarily on individual economic effectiveness - conceptualised through abstract holders of human capital - towards policies that combine the issue of human resources development with the question of structural inequalities in (mathematics) education and the wider society.

Key words: mathematics education, human capital, high status knowledge, active citizenship, mathematics achievement, educational policy, post-industrial society 